\title{
Osseointegration of machined and anodized implants under the influence of nicotine
}

\author{
Osseointegração de implantes usinados e anodizados sob a influência da nicotina
}

\author{
Maria Salete Sandini LINDEN ${ }^{1}$ \\ Daniela Cristina MIYAGAKI² \\ Francisco Carlos GROPPO 3 \\ Fábio André dos SANTOS 4 \\ João Paulo De CARLI ${ }^{5}$ \\ Juliana Camma RAMACCIATO ${ }^{6}$
}

\section{ABSTRACT}

\section{Objective}

The objective of this experimental study was to evaluate, through bone densitometry, the performance of two factors that may influence the osseointegration process: nicotine and superficial texturization of the implants.

\begin{abstract}
Methods
Nineteen New Zealand rabbits (Oryctolagus cuniculus) were randomly distributed in two groups (test and control), in which 38 implants were placed. 19 machined implants (flat) $3.75 \mathrm{~mm}$ of diameter by $6.0 \mathrm{~mm}$ length were placed at the right tibia of the animals and, at the left tibia, 19 anodized implants (Vulcano ${ }^{\circledR}$ ) with the same dimensions. Subcutaneous injections of nicotine 3m//day/kg, three times a day were administered in group, group control also received, three times a day, subcutaneous solution of NaCl (3m//day/kg), for 8 weeks. After this period, the densitometry analysis was performed.
\end{abstract}

\section{Results}

Considering the optical density (pixels), there were no statistical significant differences between the types of implants ( $p=0.135)$ as well as between groups $(p=0.590)$.

\section{Conclusion}

The nicotine inside the experimental conditions used in this study and the superficial texturization of the implants indicated that they were not influencing bone density.

Indexing terms: Dental implants. Densitometry. Nicotine. Osseointegration.

\section{RESUMO}

\section{Objetivo}

Avaliar por meio de densitometria óssea o comportamento de dois fatores que podem inteferir no processo da osseointegração: a nicotina e a texturização superficial dos implantes.

\section{Métodos}

Dezenove coelhos da raça Nova Zelândia (Oryctolagus cuniculus) foram distribuídos aleatoriamente em dois grupos (teste e controle), nos quais foram colocados 38 implantes. Na tíbia direita dos animais foram inseridos dezenove implantes usinados (lisos) de 3,75 mm de diâmetro por $6,0 \mathrm{~mm}$ de comprimento e, na tíbia esquerda, dezenove implantes anodizados (Vulcano ${ }^{\circledR}$ ) nas mesmas dimensões. Foram administradas no grupo teste injeções subcutâneas de nicotina $3 \mathrm{ml} / \mathrm{dia} / \mathrm{kg}$, três vezes ao dia, o grupo controle recebeu igualmente, três vezes ao dia, solução subcutânea de $\mathrm{NaCl}(3 \mathrm{ml} / \mathrm{dia} / \mathrm{kg})$, por oito semanas. Após esse período, procedeu-se a análise densitométrica.

\section{Resultados}

Considerando a densidade óptica (pixels), não houve diferenças estatisticamente significativas entre os tipos de implantes ( $p=0.135)$ bem como entre os grupos $(p=0.590)$.

\section{Conclusão}

A nicotina dentro das condições experimentais empregadas neste estudo e a texturização superficial dos implantes não interferiram na densidade óssea.

Termos de indexação: Implantes dentários. Densitometria. Nicotina. Osseointegração.

\footnotetext{
${ }^{1}$ Universidade de Passo Fundo, Faculdade de Odontologia, Departamento de Medicina Oral. Km 171, BR 285, Campus I, São José, 99001-970, Passo Fundo, RS, Brasil. Correspondência para / Correspondence to: MSS LINDEN. E-mail: <linden@upf.br>.

${ }^{2}$ Universidade de Passo Fundo, Faculdade de Odontologia, Departamento de Endodontia. Passo Fundo, RS, Brasil.

${ }^{3}$ Universidade Estadual de Campinas, Faculdade de Odontologia, Departamento de Ciências Fisiológicas. Piracicaba, SP, Brasil.

${ }^{4}$ Universidade Estadual de Ponta Grossa, Departamento de Ciências da Vida e Saúde. Ponta Grossa, PR, Brasil.

${ }^{5}$ Universidade de Passo Fundo, Faculdade de Odontologia. Passo Fundo, RS, Brasil.

${ }^{6}$ Faculdade São Leopoldo Mandic, Curso de Odontologia. Campinas, SP, Brasil.
} 


\section{INTRODUCTION}

The success of the osseointegration has been constantly associated with bone density quality that can be impaired, among other causes, due to smoking. Various authors confirmed this deleterious effect in moderate and heavy smoking patients, mainly when implants are placed in their maxilla, with relation to slight and non-smokers ${ }^{1-2}$.

Therefore, Yuhara et al. ${ }^{3}$ associated nicotine with the increase of the calcium ion removal, the production of alkaline phosphatase and the reduction of the osteoclastic activity, whereas Iwaniec et al. ${ }^{4}$ did not find any loss of volume, resistance or bone mass with serum concentrations of nicotine which are superior to those that were found in smoking when the exposure of female rats that are growing with nicotine for two or three months.

Animal models with varied protocols in the use of nicotine have been often tested through subcutaneous injections, inhalation of cigarette smoke or subcutaneous osmotic mini-pumps, evaluating its influence in the bone repair of implants ${ }^{5-6}$.

Long-term studies demonstrated that implants of titanium of rough surface presented greater bone loss in smokers than in non-smokers, mainly when they were placed in maxilla ${ }^{7}$. Kumar et al. ${ }^{8}$ found out that in one period of 18 months the habit of smoking did not play a significant role in obtaining osseointegration with implants of modified surface.

Although osseointegration can be reached successfully, using flat and rough surfaces of implants, some experimental studies have demonstrated greater values of bone/implant contact and torque for anodized implants when they are compared with machined implants ${ }^{9-11}$.

Therefore, the objective of this experimental study is to evaluate, by means of bone densitometry, the performance of two factors that may interfere in the osseointegration process: nicotine and superficial texturization of implants.

\section{METHODS}

This laboratorial study was approved by the Committee of Ethics in Research with Animals of Passo Fundo University (record CEP n. 535/2006).

Nineteen (19) male New Zealand (Oryctolagus cuniculus) rabbits, clinically healthy, were randomly selected according to the criteria of age (from 8 to 10 months) and weight (from 3.5 to $4 \mathrm{~kg}$ ), with blind characteristic.
They were randomly distributed into two groups (test and control), in which 38 implants were placed, that is, two for each rabbit. Machined implants (Master $\mathrm{Screw}^{\circledR}$ ) of $3.75 \mathrm{~mm}$ diameter by $6.0 \mathrm{~mm}$ length were inserted in the right tibia of the animals, and, in the left tibia, anodized implants (Master Vulcano Actives ${ }^{\circledR}$ ) were inserted using the same dimensions. Subcutaneous injections of nicotine treated (Sigma-Aldrich, ${ }^{\circledR}$ Copenhagen, Denmark AS) 3ml/ day $/ \mathrm{kg}$, three times a day were used in group test. Group control also received a subcutaneous solution of $\mathrm{NaCl}(3 \mathrm{ml} /$ day $/ \mathrm{kg}$ ) three times a day for eight weeks.

The animals were sacrificed and the bone samples with the implants were removed, submitted to digitized periapical radiographs with time exposure of $0.02 \mathrm{~s}$ (X-ray, model SALETEC X-MIND-70 kVp and 8mA with focal point of $0.7 \mathrm{~mm} \times 0.7 \mathrm{~mm}$, filtration of $2.5 \mathrm{~mm} \mathrm{Al}$ and digital sensor CCD Fimet IOX-F1 and submitted to analysis of bone densitometry.

Two measures of optical density were standardized, considering a "mesial" and "distal" of each implant, taking as an apical reference the last thread (1), and cervical, the implant platform (Figure 1 and 2).

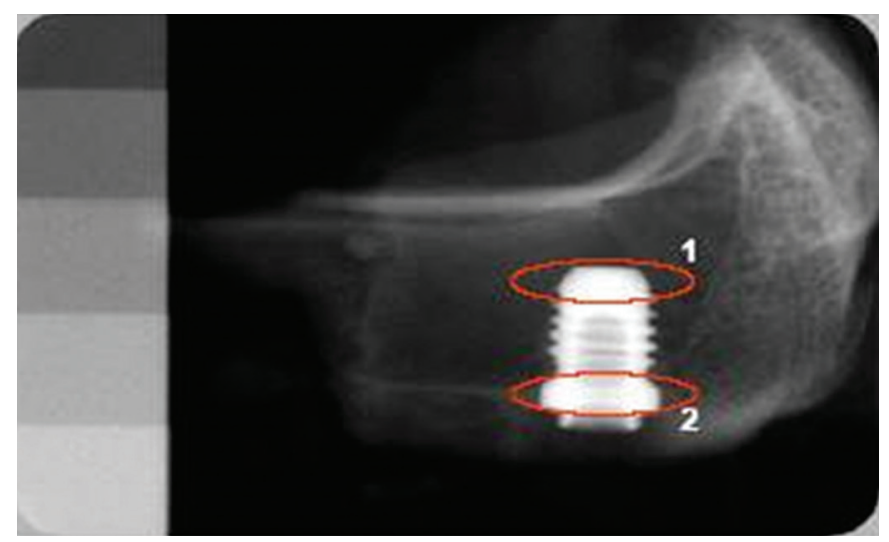

Figure 1. Definition of the area measured.

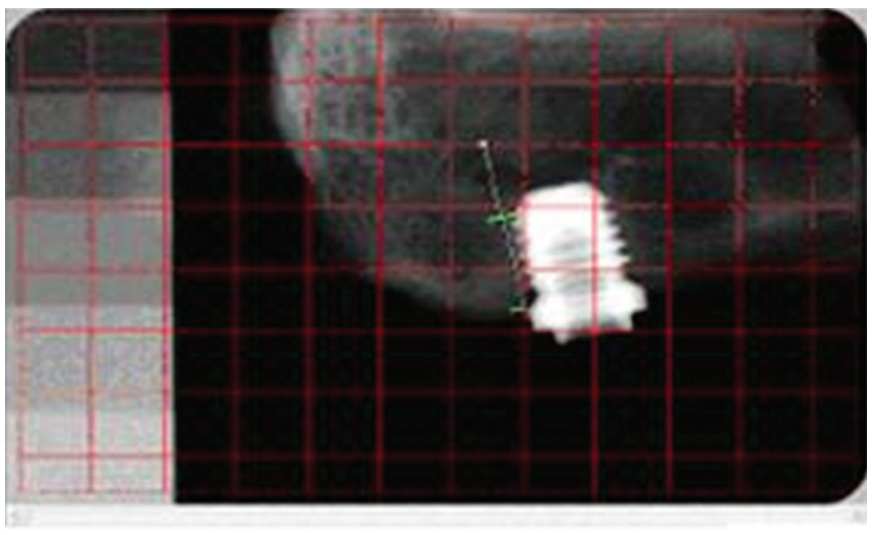

Figure 2. Optical density in the pre-determined area (green lines) using program Pro Plus 4.5. 
With program Image Pro Plus 4.5 it was determined the optical density in the pre-determined area (green lines) according to description above, which is a method that is based on the same system used to determine the densitometry in electrophoresis bands (Figure 3). In the analysis of density (pixel) of the reference for each photo, only four graduated scales were used, thus they were common to all photos.

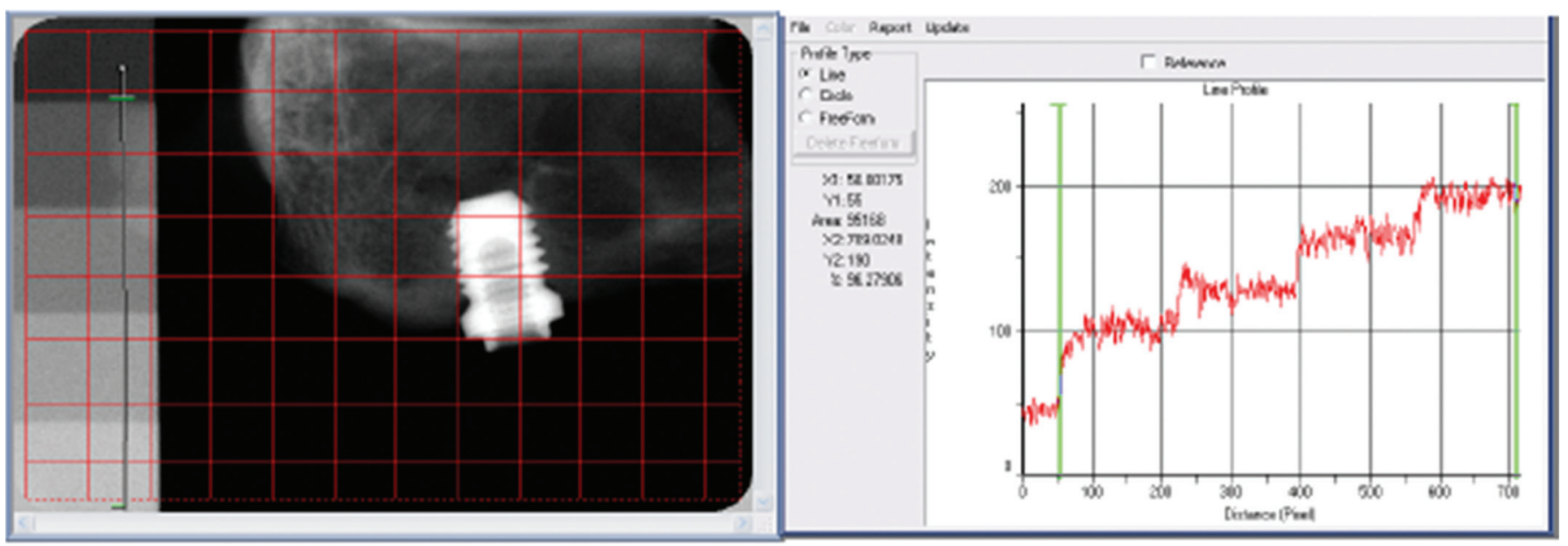

Figure 3. Analysis of the density (pixel) of the reference pattern.

Each implant length was measured according to methodological issues (position or distortion of the radiograph) (Figure 4).
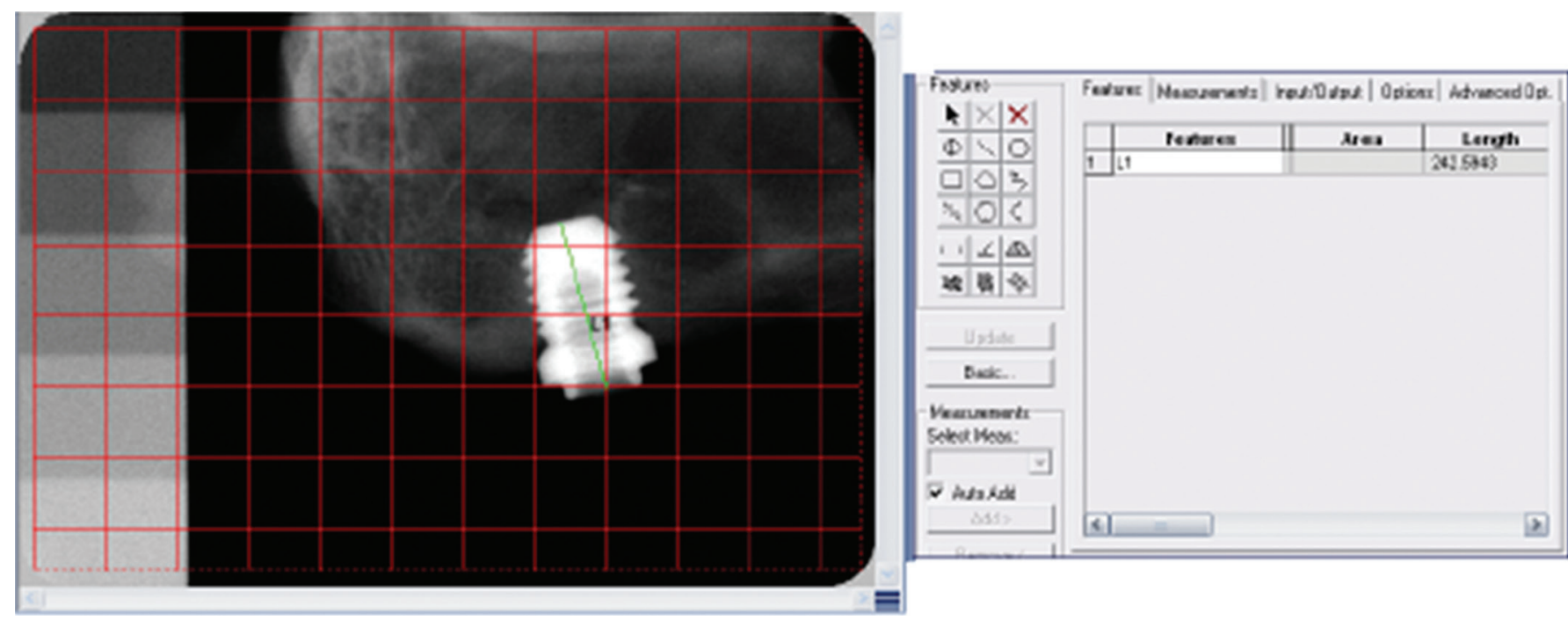

Figure 4. Correction of the data through the reference scale.

The data of optical density were analyzed by tests ANOVA and Test t student.

\section{RESULTS}

One animal of the control group and four animals of the test group were discarded, due to death before the end of the research. The results were therefore obtained from 19 healthy animals, remaining $n=8$ in the group test, and $n=11$ in the group control.

Statistically significant differences were not observed between the averages of the optical density, considering the types of implant $(p=0.135)$ and not considering groups $(p=0.590)$, that is, the nicotine 
seemed not to influence the bone density and the surface of both implants studied seemed not to promote greater bone density with relation to one another (Table 1; Figure 5 and 6).

Table 1. Description, composition, manufacturer and batch of adhesive cementation materials.

\begin{tabular}{|c|c|c|c|}
\hline \multicolumn{4}{|c|}{ Groups } \\
\hline & & Control & Treated \\
\hline Densitometry & Machined (flat) & $105 \pm 28.78$ & $109.2 \pm 32.01$ \\
\hline
\end{tabular}

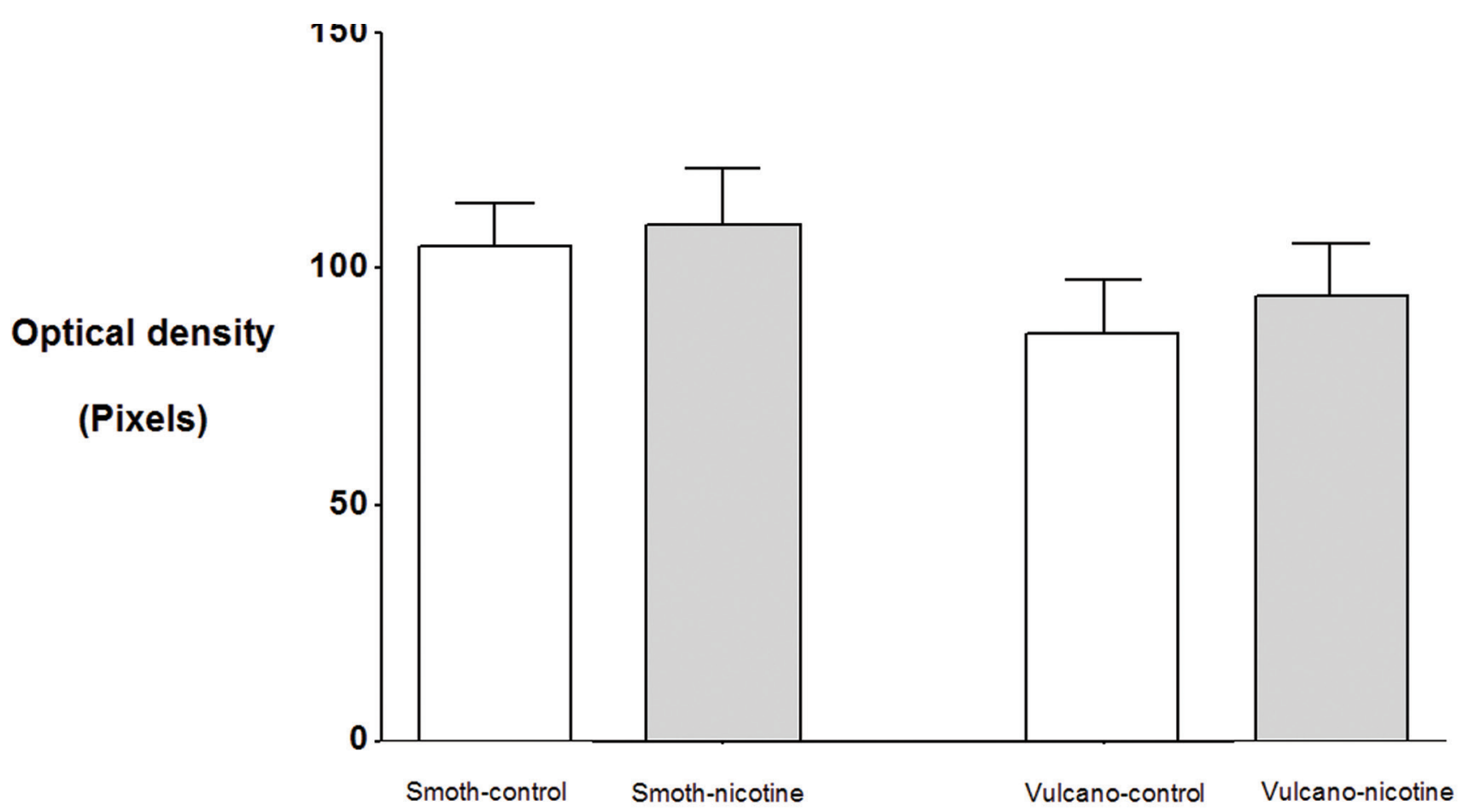

Figure 5. Comparison between groups control and test, surfaces of implants and bone density.

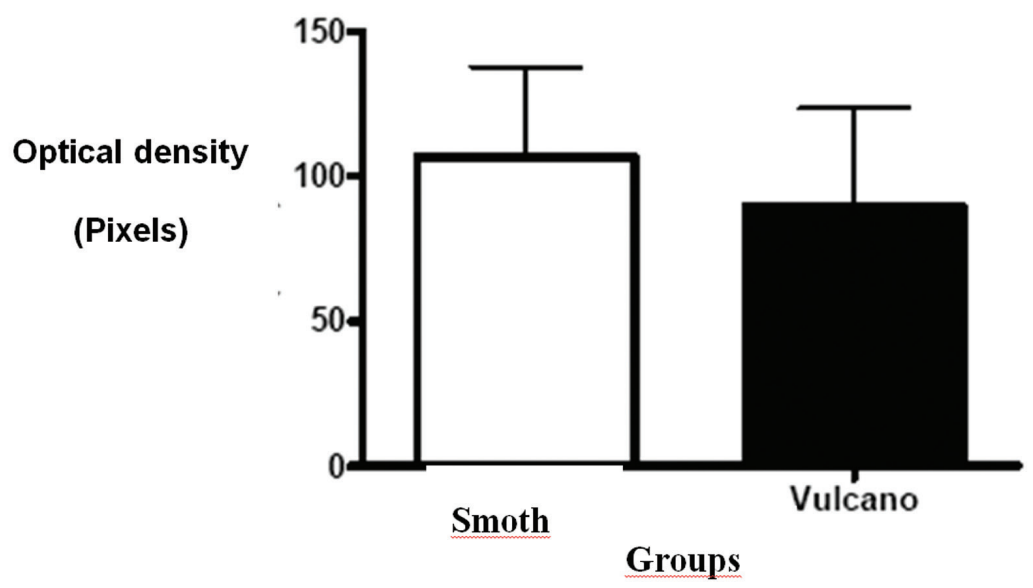

Figure 6. Average and standard deviation of the optical density ot the bone tissue around both types of implants in the rabbits' tibia. Non-signiticant ditterences between groups Note: ( $p=0.1205$ - Test t student) 


\section{DISCUSSION}

The chemical effect of the nicotine inhaled, added to tobacco, in the indexes of mineral serumal and calcium hormones in adult rats was investigated by Iwaniec et al. ${ }^{12}$ and Syversen et al. ${ }^{13}$ in order to elucidate controversy, approaching the impact of nicotine in bone integrity. Such authors observed that the treatment with nicotine did not have effect on the medular bone or tibia cortical turnover or on the content and mineral bone density. In this present study, although the nicotine has been injected instead of using it via inhalation, there were no differences between the groups studied.

Cesar-Neto et al. ${ }^{14}$, when reviewing the influence of nicotine in implants osseointegration, considered two conditions: cigarette smoke inhalation and the subcutaneous administration ( $3 \mathrm{mg} / \mathrm{kg}$ ) twice a day, and then they concluded that the negative impact of cigarette in the implants may happen because there is more than one molecule present in the cigarette smoke and that nicotine seems to contribute to it. In the study where subcutaneous nicotine was administered three times a day, there was no statistical difference between the groups studied, demonstrating that nicotine did not influence on bone density, probably because it has been injected subcutaneously instead of being inhaled along with other cigarette toxic components.

Yet, Cesar-Neto et al. ${ }^{15}$, led a radiograph study in 41 male rats Wistar, evaluating the influence in inhalation of cigarette smoke and the effect of its interruption in the tibia bone quality. The results showed that the continuous exposure to cigarette smoke promoted a significant reduction in bone density and the interruption of inhalation seems to reverse this negative effect. On the other hand, on the densitometric evaluation performed in this study, the daily subcutaneous injections of nicotine did not interfere in osseointegration.

In turn, Stefani et al. ${ }^{16}$, using different protocols of subcutaneous injections of nicotine, unlike this present study, found out that implants with treated surface favor the extension of the bone tissue in direct contact with the surface of the implant in animals treated with nicotine.

Peackok et al. ${ }^{17}$ and Yuhara et al. ${ }^{3}$ works reflect that nicotine in low concentrations could trigger stimulant effects to the bone tissue, corroborating the results found in the groups treated with nicotine in this work, where such chemical substance did not impair osseointegration.

The density values in this experiment (Table 1) did not show statistically significant difference between the groups, identifying with the results of previous studies $^{13,16}$

Even not showing statistical differences between implants surfaces in this study, the use of implants treated is based on the fact that osteoblasts prefer rough surfaces, cytoplasmic processes present greater mirroring, increase of the mitosis number and production of matrix components when compared with titanium machined surfaces $^{18}$.

Altered topographies of the implant surface, as an increase of the titanium oxide, seem to result in larger bone apposition upon the implant surface when they were compared with machined surfaces ${ }^{19}$. Furthermore, the type of implant used in this study (anodized) was recommended for other works, showing human blood in an angle of surface contact around 55.6 degrees that was considered excellent ${ }^{20}$.

Of the foregoing, definitive studies that evaluate the bone dynamic answer in long term and several materials and designs of implants in which biomechanical and biomaterial properties can be compared, taking into account whether or not nicotine is used.

\section{CONCLUSION}

Considering the methodology used, it is concluded that nicotine, when subcutaneously managed, using $3 \mathrm{ml} /$ day/kg three times a day, as well as texturization of machined and anodized implants, indicated not interfering in bone density.

\section{Collaborators}

MSS LINDEN, experimental clinical development. DC MIYAGAKI, review of literature. FC GROPPO, statistical analysis. FA SANTOS, bone densitometry development, JP CARLI, standardization and review of literature. JC RAMACCIATO, search guidance. 


\section{REFERENCES}

1. Kourtis SG, Sotiriadou S, Voliotis S, Challas A. Private practice results of dental implants. Part I: survival and evaluation of risk factors. Part II: surgical and prosthetic complications. Implant Dent. 2004;13(4):373-85.

2. Moy PK, Medina D, Shetty V, Aghaloo TL. Dental implant failure rates and associated risk factors. Int J Oral Maxillofac Implants. 2005:20(4):569-77.

3. Yuhara S, Kasagi S, Inoue A, Otsuka E, Hirose S, Hagiwara $\mathrm{H}$. Effects of nicotine on cultured cells suggest that it can influence the formation and resorption of bone. Eur J Pharmacol. 1999 Nov 3;383(3):387-93. doi: 10.1016/S0014-2999(99)00551-8

4. Iwaniec UT, Fung YK, Cullen DM, Akhter MP, Haven MC, Schmid $M$. Effects of nicotine on bone and calciotropic hormones in growing female rats. Calcif Tissue Int. 2000;67(1):68-74.

5. Balatsouka D, Gotfredsen $\mathrm{K}$, Lindh $\mathrm{CH}$, Berglundh T. The impact of nicotine on osseointegration. Clin Oral Implants Res. 2005;16(4):389-95. doi: 10.1111/j.1600-0501.2004.01151.x

6. Duygulu F, Karaoglu S, Zeybek ND, Kaymaz FF, Günes T. The effect of subcutaneously injected nicotine on achilles tendon healing in rabbits. Knee Surg Sports Traumatol Arthrosc. 2006;14(8):756-61.

7. Wennstrom JL, Ekestubbe A, Grondahl K, Karlsson S, Lindhe J. Oral rehabilitation with implant-supported fixed partial dentures in periodontitis susceptible subjects. A 5-year prospective study. J Clin Periodontol. 2004;31(9):713-24. doi: 10.1111/j.1600-051X.2004.00568.x

8. Kumar A, Jaffin RA, Berman C. The effect of smoking on achieving osseointegration of surface-modified implants: a clinical report. Int J Oral Maxillofac Implants. 2002;17(6):816-9.

9. Shibli JA, Grassi S, de Figueiredo LC, Feres M, lezzi G, Piattelli A. Human peri-implant bone response to turned and oxidized titanium implants inserted and retrieved after 2 months. Implant Dent. 2007;16(3):252-9.

10. Rezende MCRRA, Wada CM, Lopes MRANE, Capalbo LC, Gonçalves VM, Valente ADB, et al. O papel da adsorção de proteínas na osseointegração. Arch Health Invest. 2015;4(3):18-25.

11. Guerra YE, Guerra YE, Martín DL, González RC, Molerio RC. Hábito de fumar asociado a enfermedades periodontales. MediCiego. 2015;21(3):10-16.
12. Iwaniec UT, Fung $Y K$, Akhter MP, Haven MC, Nespor $S$ Haynatzki GR, et al. Effects of nicotine on bone mass, turnover, and strength in adult female rats. Calcif Tissue Int 2001;68(6):358-64

13. Syversen U, Nordsletten L, Falch JA, Madsen JE, Nilsen OG, Waldum HL. Effect of lifelong nicotine inhalation on bone mass and mechanical properties in female rat femurs. Calcif Tissue Int 1999 Sep;65(3):246-9.

14. César-Neto JB, Duarte PM, Sallum EA, Barbieri D, Moreno Jr $\mathrm{H}$, Nociti Jr FH. A comparative study on the effect of nicotine administration and cigarette smoke inhalation on bone healing around titanium implants. J Periodontol. 2003;74(10):1454-9. doi: 10.1902/jop.2003.74.10.1454

15. César-Neto JB, Benatti BB, Manzi FR, Sallum EA, Sallum AW Nociti Junior $\mathrm{FH}$. The influence of cigarette smoke inhalation on bone density: a radiographic study in rats. Braz Oral Res. 2005;19(1):47-51. doi: 10.1590/\$1806-83242005000100009

16. Stefani CM, Filho GRN, Sallum EA, Toledo SD, Sallum AW Nociti Jr FH. Influence of nicotine administration on different implant surfaces: a histometric study in rabbits. J Periodontol. 2002;73(2):206-12. doi: 10.1902/jop.2002.73.2.206

17. Peacock ME, Sutherland DE, Schuster GS, Brennan WA, O'Neal $\mathrm{RB}$, Strong SL, et al. The effect of nicotine on reproduction and attachment of human gingival fibroblasts in vitro. J Periodontol. 1993;64(7):658-65. doi: 10.1902/jop.1993.64.7.658

18. Mesquita $P$, Felino A, Raposo $H$, Afonso A. Avaliação in vitro do comportamento de osteoblastos sobre implantes com diferentes tratamentos de superfície. Rev Port Estomatol Med Dent Cir Maxilofac. 2015;56(2):95-102. doi: 10.1016/j. rpemd.2015.04.006

19. Martin JY, Schwartz Z, Hummert TW, Schraub DM, Simpson J, Lankford J, et al. Effect of titanium surface roughness on proliferation, differentiation, and protein synthesis of human osteoblast-like cells (MG63). J Biomed Mater Res. 1995;29(3):389-401.

20. Elias CN, Lima JHC, Silva Filho RC, Muller CA. Interações de células com diferentes superfícies de implantes dentários. Rev Bras Odontol. 2005;62(1/2):119-24.
Received on:26/8/2015

Final version resubmitted on:10/12/2015

Approved on: 24/2/2016 